\title{
Dominion Hardware Inc.
}

M. Nauman Farooqi, Ph.D., Mount Allison University, Canada

\begin{abstract}
On Monday morning November 20, 2005 Peter Seitz, President of Dominion Hardware Inc. (DHI) headquartered in Windsor Ontario, wanted to start planning for the meeting with his two partners scheduled for December 11, 2005. It had been two months since the trio had bought the company. The purpose of the meeting was to find ways of financing the expansion of DHI over the next five years.
\end{abstract}

Keywords: Ratio Analysis, Financing Analysis, Financial Issues, Inventory Management, Working Capital Management, Entrepreneurship, Entrepreneurial Finance.

\section{DOMINION HARDWARE BACKGROUND}

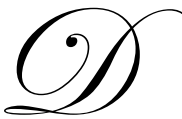

HI was incorporated in October 1972 as a Canadian Federal Corporation and as a wholly owned subsidiary of Grand Hardware Inc., USA. DHI opened its first store in Windsor, Ontario in November 1972. The company briefly expanded in Quebec but due to poor sales decided to concentrate on the Ontario market. By offering a variety of hardware, farm equipment, supplies and quality personalized service DHI gradually expanded to the current 17 stores with sales of over \$84 Million in 2005 (see Exhibits 1 \& 2). In July 1990 the US parent sold the company to three members of the DHI management team led by the former President, Mr. Arnold Smith.

\section{THE BUYOUT}

In early 2005, Mr. Smith and partners decided to sell the business. They were aware of the opportunities for DHI, but given their risk-averse temperament, they were not interested in pursuing a management overhaul and the investment required to take the company forward. Peter Seitz, Neil Welch and Robert Miller, who had worked for DHI for the last several years, decided to look into the prospect of buying the business from the current owner. Being veterans in the hardware business, the trio felt that the purchase of the company would be a good investment with bright future prospects. By pooling their personal financial resources and relying heavily on debt, secured by the significant real estate assets of the company, the trio made an offer. The deal went through in October 2005.

The partners expected a payback period of five years. They hoped to grow the company from the present 17 stores to at least 30 by the end of five years. They figured that a 30-store chain would be a saleable company and be able to generate substantial profits for them.

\section{FINANCING OPTIONS}

Given the payback period target of five years, Peter calculated that the company needed to add at-least two new stores each year. Each new store involved an expense of about $\$ 3.5$ million. The largest portion of this $\$ 3.5$ million ( $\$ 1$ million) was needed for stocking inventory in the new store. The other expenses involved land and buildings, costing $\$ 2$ million and the balance was for staff, training and opening expenses. The previous owners expansion philosophy was to build and own new stores. Given the current leveraged position of the company, Peter knew that the possibility of getting outside financing for the proposed expansion was extremely remote. The partners had debated the possibility of adding another partner or seeking public money (through an IPO) but were concerned about the dilution of ownership and sharing of management control.

Peter knew he had to find the funds needed for expansion internally; the question was from where and how. He started his search by looking at inventory, which represented a substantial amount of current assets. The 
company currently used a cross-docking inventory management system in which shipments were received at the corporate office warehouse and immediately split into 17 parcels with one shipped to each of the 17 stores. The system relied on the "push" strategy to ship inventory to the stores. The amount shipped to different stores was not based on their level of sales or need, resulting in instances where the company had to move inventory from one store to another to meet demand. Peter estimated that the company could easily reduce each store's inventory by $\$ 200,000$ by replacing the existing "push" inventory management system with a "pull" or auto-replenishment system. This would free up about $\$ 3.5$ million, which could be used to finance the proposed expansion strategy. As Peter thought about this option he realized that the use of an auto-replenishment system would require DHI to monitor and track the exact movement of its inventory in each of the 17 stores. Peter realized that given the current fifteen-year-old Point of Sale (POS) system, this would be difficult to achieve. The best the company could do with the present system was to track inventory for a week prior. A new POS system would cost about \$1 million including equipment, communications, staff, training and installation.

\section{EXHIBIT 1}

Dominion Hardware Inc.

Balance Sheet as at December 31

\begin{tabular}{|c|c|c|}
\hline & 2005* & 2004 \\
\hline \multicolumn{3}{|l|}{ Assets } \\
\hline \multicolumn{3}{|l|}{ Current assets } \\
\hline Accounts receivable - Trade & $1,209,814$ & 983,293 \\
\hline - Other & 118,623 & 257,804 \\
\hline Inventories (net of an allowance of $\$ 948,000,2004-\$ 885,000$ ) & $25,382,517$ & $23,618,842$ \\
\hline \multirow[t]{2}{*}{ Prepaid expenses and deposits } & 324,653 & 252,348 \\
\hline & $27,035,607$ & $25,112,288$ \\
\hline Future income tax benefit & 134,194 & 60,303 \\
\hline Capital assets & $17,815,973$ & $13,613,378$ \\
\hline Total Assets & $44,985,774$ & $38,785,968$ \\
\hline \multicolumn{3}{|l|}{ Liabilities and Equity } \\
\hline \multicolumn{3}{|l|}{ Current liabilities } \\
\hline Bank indebtedness, net & $4,291,928$ & $3,640,954$ \\
\hline Accounts payable and accrued liabilities & $8,686,372$ & $9,889,330$ \\
\hline Income taxes payable & $3,579,135$ & $2,881,298$ \\
\hline Current portion of long-term debt & $1,348,285$ & 946,817 \\
\hline \multirow[t]{2}{*}{ Current portion of capital lease obligations } & 200,077 & 252,575 \\
\hline & $18,105,798$ & $17,610,973$ \\
\hline Long-term debt & $7,046,337$ & $4,132,261$ \\
\hline Capital lease obligations & 160,092 & 275,564 \\
\hline Share capital & $16,094,411$ & $13,885,871$ \\
\hline \multirow[t]{2}{*}{ Retained Earnings } & $3,579,135$ & $2,881,298$ \\
\hline & $19,673,546$ & $16,767,169$ \\
\hline Total Liabilities and Equity & $44,985,774$ & $38,785,968$ \\
\hline
\end{tabular}

*The financial statements for the year 2005 do not show the increased leverage position as the reporting year ended in August 2005, i.e. before the buyout deal took place.

Another related issue to the expansion project was the warehouse space available at the corporate headquarters. The existing facility was just large enough to cater to the inventory needs of the 17 stores. Under the current inventory management system, any increase in the number of stores would require expansion and/or reorganization of the physical storage facilities. However, given the new inventory management option that he was looking into and with reorganization of the existing space, Peter thought that he could easily service 30 stores from 
the existing facility. The cost of this reorganization for the auto-replenishment inventory system would be $\$ 500,000$ and would include new shelving, new forklifts and additional staff.

As the day passed, Peter thought about the various options and tried to come up with a plan to present to the partners. He also thought of looking into comparative ratios (Exhibit 3) for other hardware companies to get some ideas as to his company's comparative standing and performance. He knew that the growth strategy was an absolute must if the partners were to realize their investment objectives. The question was where to begin.

\section{EXHIBIT 2}

Dominion Hardware Inc. Income Statement

\begin{tabular}{|c|c|c|}
\hline & 2005* & 2004 \\
\hline Sales & $84,098,582$ & $71,622,931$ \\
\hline Cost of Sales & $56,317,788$ & $47,841,994$ \\
\hline Net Sales & $27,780,794$ & $23,780,937$ \\
\hline Freight Brokerage & $1,107,137$ & $1,049,599$ \\
\hline Gross Profit & $26,673,657$ & $22,731,337$ \\
\hline Personnel & $11,065,087$ & $9,169,493$ \\
\hline Occupancy & $4,807,219$ & $4,918,601$ \\
\hline Depreciation & 0 & 0 \\
\hline Advertising & $2,005,682$ & $1,690,629$ \\
\hline Operating & $1,151,386$ & $1,101,481$ \\
\hline & $19,029,374$ & $16,880,205$ \\
\hline Operating Profit & $7,644,284$ & $5,851,133$ \\
\hline Bank Charges & 288,664 & 582,767 \\
\hline Interest & 691,580 & 0 \\
\hline Rental Income & 494,230 & 494,230 \\
\hline Income before Tax & $7,158,270$ & $5,762,596$ \\
\hline Income Taxes (@50\%) & $3,579,135$ & $2,881,298$ \\
\hline Net profit & $3,579,135$ & $2,881,298$ \\
\hline
\end{tabular}

*The financial statements for the year 2005 do not show the increased leverage position as the reporting year ended in August 2005 , i.e. before the buyout deal took place.

\section{EXHIBIT 3}

Comparative financial ratios for the hardware industry for 2005

\begin{tabular}{|l|c|c|}
\hline \multicolumn{1}{|c|}{ Ratios for Year 2005 } & Industry & Dominion Hardware \\
\hline Profit Margin & & $8.50 \%$ \\
\hline Gross Profit Margin & $5.20 \%$ & $32.00 \%$ \\
\hline Asset Turnover & $32 \%$ & 1.87 \\
\hline Days Inventory & 2.24 & 165 \\
\hline Inventory Turnover & 87 & 2.2 \\
\hline Current Ratio & 4.2 & 1.5 \\
\hline Debt to Total Assets & 1.8 & 0.5 \\
\hline
\end{tabular}




\section{Teaching Note:}

\section{DOMINION HARDWARE INC.}

\section{Synopsis:}

The case addresses some of the issues involved in financial management in an entrepreneurial setting. The case develops the student's ability to compare financial statements and ratios and to distill critical information for decision-making. The case revolves around the decision faced by Peter Seitz, President of a hardware company, who has to evaluate various options and their pros and cons to finance the company's expansion over the next five years. In doing so, the case exposes the students to leverage, working capital management, financing issues and the use of lease financing.

\section{Situation:}

On Monday morning November 20, 2005 Peter Seitz, President of Dominion Hardware Inc. (DHI) headquartered in Windsor Ontario, was preparing for the meeting with his two partners planned for December 11, 2005. It had been two months since the trio had bought the company. The purpose of the meeting was to find ways of financing expansion of DHI over the next five years.

\section{Intended Course and Audience:}

The case can be used in an introductory finance, introductory accounting or an entrepreneurial finance course. The case can also be used an introductory case for executive training courses such as Finance for NonFinance Managers.

\section{Immediate Issues:}

1. Develop a list of financing options for the partner's meeting.

2. Evaluate the pros and cons for each of the options and prioritize them.

3. Find ways to finance POS and the warehouse re-organization.

4. Suggest a course of action.

\section{Basic Issues:}

1. Ratio Analysis and comparison

2. Working Capital Management

3. Inventory Management

4. $\quad$ Financing issues

5. Leverage

6. Prioritization of options

7. Lease financing

\section{Teaching Objectives:}

1. Make students aware of the issues involved in financial management in an entrepreneurial setting.

2. Develop student's ability to compare financial statements and ratios and use the comparison for decisionmaking.

3. The importance of use of leverage and its limitations for restricting access to future debt financing.

4. Identify the importance of inventory in working capital management.

5. Stress the importance of fine-tuning operations to generate internal funds for future growth and investment.

6. Provide students the opportunity to develop various options, evaluate pros and cons for each and suggest a course of action.

7. Lease financing.

8. Decision-making. 


\section{Teaching Plan:}

The case can be used to introduce students to the case methodology at the same time introducing them to some basic financial analysis issues. The case can be delivered in a sixty or ninety minute class session. Students must have been exposed to basic financial and ratio analysis and be comfortable with calculating and comparing ratios. After a brief size up of the case, the discussion should move to the list of suggested student assignment questions (see below). This part of the session should focus on the various options available to Peter and the pros and cons associated with each option. Through discussion and Q\&A, students should be encouraged to look at the various options and the impact each would have on the future financial profitability of the company. The discussion should highlight the impact one decision can have on the whole enterprise. Issues relating to the economy, market conditions and competition should also be brought to light through discussion and Q\&A. The discussion should then proceed to identify other options that Peter could consider. The various other options and their pros and cons should be discussed. Finally, the students should be asked to prioritize the options and come up with a plan to present them at the partner's meeting. Data and other information needed to provide support for the most desirable option should be discussed. The case should wrap up with highlighting the application of financial analysis tools for management's decision-making.

\section{Suggested student assignment:}

1. Given the critical issue of financing growth at DHI, how should Peter evaluate the various options he is considering? Discuss the pros and cons of each option.

2. Apart from the options indicated in \# 1, can you suggest other options for financing future growth at DHI? Provide details.

3. Based on your answers to questions 1 and 2 how should Peter prioritize and present the options at the partner's meeting? What course of action should he suggest?

\section{Responses to suggested student assignments:}

Given the fact that finding funds for growth is critical for the partner's investment goals, the following options are available:

a. Add another partner who may inject the funds needed for financing growth.

b. Take the company public.

c. Pull out money from the excess inventory and use the funds for financing growth.

i. Related to this issue is the fact that in order to pull out money from inventory the company will need to have a new POS system, which will cost $\$ 1$ million.

ii. Also related to this issue is the $\$ 500,000$ that is needed to manage the new inventory system at the company's corporate warehouse.

Adding another partner seems to be the easiest way out. The issues concerning this option are the amount of money that the new partner will be investing in the business and the ownership stake that he/she would demand in return. The case mentions that the three partners are not willing to take on another partner because they do not want to dilute their ownership and as such their future return. The fact that they did not include another partner at the beginning of the deal also points in the direction that this option would be listed as one of the least desirable.

The issue of taking the company public is another one that Peter can look into. The basic idea behind taking a company public by entrepreneurs is to realize return on their investment and to finance the future growth of the firm. The case points out that the company in its existing form, with 17 stores, is not a very marketable product. They see the company as being an attractive product if it were to grow to a 30-store chain. Thus it will be difficult to get the investors excited about investing in the company right now. Peter may aim for the public floatation but he is likely not to get a warm response from investors. Also a public offer would entail the partners losing control of the company, which is critical for them at this point in time. This option is also seems not very desirable. 
The third option is an interesting one but requires the investment of about $\$ 1.5$ million to make it happen, money which, it seems, is just not available right now.

The student should start by having a look at the financial statements of the company and calculating some ratios and comparing them to the industry standards. The student will notice that the inventory turnover ratio for DHI is below the industry standards reinforcing Peter's belief that there is a possibility of reducing inventory and pulling out money from this source to finance the growth.

The financial statements for the year 2005 do not show the increased leverage position as the reporting year ended in August 2005, i.e. before the buyout deal took place. The students have, however, been informed in the case that the company is currently highly leveraged and as such the option of raising any more debt is out of the question.

Given the situation, the new inventory management system seems to be the way to go. The question now is how to finance the $\$ 1.5$ million needed for the POS and warehouse reorganization. It is here that the students can look into opportunity of using leasing to get the project rolling. The company can pay for these assets by getting the POS and warehouse equipment on a lease. The financial statements show that the company has a healthy cash flow to pay for the lease expenses.

Peter can suggest that the partners approve the implementation of the new inventory management system and finance the new POS and warehouse equipment through leasing. Once the POS and the warehouse systems are in place the company can start pulling down inventory and use the finances to fuel growth.

Peter may also recommend the partners to look into the option of leasing stores rather than building and owning them. This would also substantially cut down on the cost of adding new stores to the chain.

\section{Other Case Details:}

This case is based on field research, which included detailed meetings with key company executives, access to financial and other company data. The name of the company, executives, location and other identifying information and financial data has been disguised on the request of the company to protect confidentiality.

\section{Suggested Student Readings:}

Chapter 2, "Accounting Statements and Cash Flow" and Chapter 3, "Financial Planning and Growth". Textbook: Corporate Finance. Ross, Westerfield, Jaffe and Roberts. Fourth Canadian Edition. McGraw-Hill Ryerson.

Chapter 2, "Review of Accounting" and Chapter 3, "Financial Analysis". Textbook: Foundations of Financial Management. Block, Hirt and Short. Seventh Canadian Edition. McGraw-Hill Ryerson.

\section{AUTHOR INFORMATION}

Dr. M. Nauman Farooqi is an Associate Professor at the Department of Commerce, Mount Allison University in Canada. Dr. Farooqi received his MBA and PhD. (major finance, minor marketing) from St. Louis University. He was awarded the Paul Pare Excellence Award in recognition of excellence in both teaching and research at Mount Allison University in 2005 and 2006. His research interests lie in the areas of teaching pedagogy and Informal Value Transfer Systems (IVTS). He has worked as a consultant with national and international organizations, including the United Nations Development Program and The World Bank. 